\title{
Use of Platelet-Rich Plasma for Patellar Tendon and Medial Collateral Ligament Injuries: Best Current Clinical Practice
}

\author{
Isabel Andia, PhD ${ }^{1}$ Nicola Maffulli, MD, PhD, FRCS (Orth) ${ }^{2,3}$ \\ ${ }^{1}$ Regenerative Medicine Laboratory, BioCruces Health Research \\ Institute, Cruces University Hospital, Barakaldo, Spain \\ 2 Musculoskeletal Disorders, University of Salerno School of Medicine \\ and Surgery, Salerno, Italy \\ Address for correspondence Nicola Maffulli, MD, PhD, FRCS (Orth), \\ Musculoskeletal Disorders, University of Salerno School of Medicine \\ and Surgery, Via Salvatore Allende, Salerno 80084, Italy \\ (e-mail: n.maffulli@qmul.ac.uk).
}

${ }^{3}$ Centre for Sport and Exercise Medicine, Queen Mary University of London, Barts and the London School of Medicine and Dentistry, Mile End Hospital, London, United Kingdom

J Knee Surg 2015;28:11-18.

\begin{abstract}
Keywords

- tissue regeneration

- signaling proteins

- biological therapy

Platelet-rich plasmas (PRPs) are complex molecular therapies prepared from the patient's own blood through minimal manipulation. Clinical studies examining the efficacy of PRPs to manage patellar tendinopathy and medial collateral ligament (MCL) injuries have been reviewed. We found three controlled trials, two of them randomized, and seven case series in the management of patellar tendinopathy. In addition, three other randomized studies showed that PRPs help to regenerate the patellar tendon harvest site for anterior cruciate ligament reconstruction and to reduce patellar donor site morbidity. On the other hand, the use of PRP in MCL injuries is reported in a single case study. Seven of the 11 studies used leukocyte and PRP which was buffered in four studies. Seven of the 11 studies applied two or three injections. Given the heterogeneity of PRP protocols and the paucity of high-quality data, the most effective approach to guide clinical decisions regarding patellar tendinopathy cannot be deduced from the present published studies.
\end{abstract}

Patellar tendinopathy (PT), also named jumpers knee, is an overuse injury characterized by activity-related anterior knee pain, most often showing lesions at the inferior pole of the patella, even though the midzone, paratenon, tibia tubercle or superior pole can also be affected.

PT is common among professional and recreational athletes ${ }^{1}$ involved in sports with high demand of the knee extensors, in particular volleyball and basketball. ${ }^{2}$ In this context, intrinsic risk factors such as patellar shape ${ }^{3}$ and athlete's age, or extrinsic risk factors involving playing at high level competition, hours of training per week, and training errors among others make athletes vulnerable to PT. ${ }^{4}$ So far, most research involves professional and recreational athletes. The personal and economic burden of PT is high, because swelling and pain impairs performance with

received

April 2, 2014

accepted after revision

June 4, 2014

published online

July 4, 2014 loss of function (jumping and kneeling), often leading athletes to abandon their career. ${ }^{5}$

Several nonoperative treatment modalities can be used to manage PT, including a variety of injectable substances with different mechanisms of action such as corticoids, polidocanol or platelet-rich plasma (PRP). The effect of high volume injections to mechanically modify the tissue has been explored both in chronic $\mathrm{PT}^{6}$ and recalcitrant medial collateral ligament (MCL) injuries. ${ }^{7}$ In addition, physical therapies (mainly eccentric training) and extracorporeal shock wave therapy (ESWT) are used. While some evidence supports the efficacy of eccentric exercises, not enough data demonstrate the effectiveness of polidocanol injection or ESWT. ${ }^{8}$ Their efficacy may depend on the phase of PT. Here, we review the available data on the efficacy of PRP injections in the management of PT.
Copyright $\odot 2015$ by Thieme Medical Publishers, Inc., 333 Seventh Avenue, New York, NY 10001, USA. Tel: +1(212) 584-4662.
DOI http://dx.doi.org/ 10.1055/s-0034-1384671. ISSN 1538-8506. 
Typical histopathological features of PT include collagen bundles separated by mucoid tissue, increased cellularity, extensive neovascularity, as well as clefts in collagen, and occasionally necrotic fibers suggesting microtears. ${ }^{9}$ From a molecular point of view, alterations in the mechanical environment, that is, disintegrated collagen fibers and loss of cell attachment, modify the microenvironment ${ }^{10}$ and affect a range of biological processes. The latter may be molecularly described as a dysregulation of inflammatory and angiogenic molecules, including prostaglandin E2, interleukin 6, interleukin 6 receptor, cyclooxygenase 2, vascular endothelial growth factor, oncostatin M, leukemia inhibitory factor, connective tissue growth factor ${ }^{11}$ as well as unbalanced anabolic/catabolic mediators. ${ }^{12}$ In this context, PRP therapy, a multimolecular approach influencing inflammation, angiogenesis, and cell metabolism, ${ }^{13}$ is increasingly used to manage pathological tendons both in the upper and lower limb ${ }^{14}$ with variable efficacy between tendons.

PRP therapies are easy to implement, and are considered safe because they are prepared through minimal manipulation of the patients' own blood. But elucidating the effect of these therapies on patient outcomes requires careful analysis of PRP products and protocols, and methodological characteristics of the study to identify the most promising approaches. In this review, we examine clinical studies exploring the efficacy of PRP injections in PT and MCL injuries, seeking to identify under what conditions PRP works.

\section{Methods}

We searched for peer-reviewed original articles in the PubMed and Web of Science databases using the following keywords, and their different combinations: "platelet-rich plasma," "jumpers' knee," "patellar tendon," "patellar tendinopathy," and "medial collateral ligament" from January 2003 to January 2014. We also searched the authors own personal files. Only articles published in English were reviewed.

\section{Study Selection and Data Collection}

We have included all clinical studies, that is, case series, controlled nonrandomized and controlled randomized studies.

Extraction of data consists of study design, patient population, intervention, that is, type of PRP formulation, volume and number of injections and interval between injections, control treatment, outcome measurements, follow-up, and the reported results.

\section{Results}

\section{Platelet-Rich Plasma Injections in Patellar Tendinopathy}

PRP injections to manage PT were reported in a total of 226 patients, including three controlled studies ${ }^{15-17}$ and eight case series studies $^{18-25}$ ( - Table 1 ). Two randomized clinical trials, one including 23 patients, ${ }^{15}$ and the other, ${ }^{16} 46$ patients, have been published recently (2013-2014). In a randomized controlled trial (RCT) comparing one leukocyte and
PRP (L-PRP) injection ( $n=9$ patients) and eccentric exercises with dry needling and eccentric exercise ( $n=12$ patients), Dragoo et al ${ }^{15}$ showed significant improvement in clinical outcomes, in visual analog score (VAS) and Victoria Institute of Sport Assessment-patellar (VISA-P) at 12 weeks after treatment. Three patients failed treatment in the dry needling group and were rescued with PRP; their outcomes at the 26 week time-point were lost. Thus, the study is biased because patients were no longer in the treatment group they were allocated. Moreover, at 26-week follow-up the number of patients was low and there were no differences between dry needling ( $n=9)$ and the PRP injection $(n=9)$. The authors interrupted recruitment because of clinically significant differences in favor of the PRP group at 12 weeks. However, these differences vanished over 26 weeks.

Two randomized clinical trials, ${ }^{16}$ each involving 46 patients, have compared two injections of pure PRP with ESWT. Clinical outcomes, as assessed by VAS, VISA-P, and Blazina scores, showed greater improvement at 6 and 12 months in the PRP group, and the percent of responders was significantly higher in PRP than in the ESWT group. ${ }^{16}$ Given evident differences between experimental and control treatment these studies were blind merely for the outcome assessor.

In a nonrandomized controlled study, Filardo et $\mathrm{al}^{17}$ showed that three injections of L-PRP 1 week apart were superior to physiotherapy as assessed by the Tegner activity score at 6 months. In this study, subjects treated with PRP had previously failed physiotherapy treatment.

Eight case series, ${ }^{18-25}$ with a variable number of patients ranging from 5 to 43 , have been published. Two ${ }^{24,25}$ of these case series included both Achilles and PT.

Regarding procedural factors, most studies (6/8) used L-PRP ${ }^{19,21-25}$; the number of injections varied from a single injection (four studies), ${ }^{21,23-25}$ two injections with 3 weeks interval (one study), ${ }^{24}$ to three injections with 2 weeks interval (two studies). ${ }^{17,18}$ All studies but one used the ultrasound (US) guidance for PRP delivery. ${ }^{17}$ The VISA-P, a standardized and validated score that allows follow-up of chronic symptoms, was used in all studies except the study by Filardo et al. ${ }^{17}$

Several studies evaluated the structural changes after treatment. ${ }^{23-25}$ Volpi et $\mathrm{al}^{23}$ reported structural improvement in $80 \%$ of the treated tendons, as assessed by magnetic resonance imaging (MRI) at 3 to 4 month posttreatment, while Ferrero et $\mathrm{al}^{24}$ reported significant changes in tendon thickness, reductions in hypoechoic areas, and decrease in intratendinous vascularity at 6 months posttreatment, but no changes at 20-day follow-up.

The effect of previous treatments and length of disease was examined in a prospective study involving 36 patients treated with one injection of buffered L-PRP. ${ }^{21}$ Although, VAS and ADL (pain during daily activities) scores improved in both groups, patients with previous treatments (ethoxysclerol, cortisone and/or surgical treatment) did not show significant changes in VISA-P over time.

Whether the effects of PRP injections lasted or not was examined by Filardo et al ${ }^{17}$ in a 4 -year follow-up study including 42 male patients and 1 female patient. The VISA-P 
Table 1 Platelet-rich plasma in the management of patellar tendinopathy

\begin{tabular}{|c|c|c|c|c|}
\hline \multicolumn{5}{|c|}{ Patellar tendon (conservative management) } \\
\hline $\begin{array}{l}\text { Study (year) } \\
\text { (Level of evidence) }\end{array}$ & $\begin{array}{l}\text { Study design, } N \\
\text { (patient population) }\end{array}$ & PRP (volume) & $\begin{array}{l}\text { Intervention/ } \\
\text { outcome } \\
\text { measurements }\end{array}$ & Follow-up/results \\
\hline $\begin{array}{l}\text { Dragoo et al }(2014)^{15} \\
\text { (Level I) }\end{array}$ & $\mathrm{RCT}, N=23$ & $\begin{array}{l}6 \mathrm{~mL} \text { L-PRP } \\
\text { (Plt: } 4-8 x \text { WBC: } 6 x \text { ), } \\
\text { buffered pH: } 7.4 \\
\text { No exogenous } \\
\text { activation }\end{array}$ & $\begin{array}{l}\text { Single injection PRP + } \\
\text { eccentric vs. } \\
\text { US-guided dry } \\
\text { needling + eccentric/ } \\
\text { VISA-P, VAS, Tegner, } \\
\text { Lysholm, SF12 }\end{array}$ & $\begin{array}{l}12,26 \text { wks/VISA-P at } \\
12 \text { wks, VAS, Tegner, } \\
\text { Lysholm, SF12 at } 12 \\
\text { and } 26 \text { wks. Better PRP } \\
\text { group at } 12 \text { wks but } \\
\text { not at } 26 \text { wks. PRP } \\
\text { accelerates the } \\
\text { recovery but effect } \\
\text { banishes over time } \\
\text { No adverse effects }\end{array}$ \\
\hline $\begin{array}{l}\text { Vetrano et al (2013) } \\
\text { (Level I) }\end{array}$ & $\begin{array}{l}\text { RCT, } N=23 \text { per group } \\
\text { Athletes, chronic }>6 \\
\text { mo recalcitrant }\end{array}$ & $\begin{array}{l}2 \mathrm{~mL} \text { pure PRP } \\
\text { Plt: } 3-5 x\end{array}$ & $\begin{array}{l}\text { Two PRP injections, } \\
\text { biweekly, US-guided } \\
\text { vs. ESWT/VAS, VISA-P, } \\
\text { Blazina scale }\end{array}$ & $\begin{array}{l}2,6 \text {, and } 12 \text { mo/VISA-P } \\
\text { and VAS, PRP better at } \\
6 \text { and } 12 \text { mo, no } \\
\text { differences at } 2 \text { mo; } \\
\text { Blazina PRP better at } \\
12 \text { mo; PRP higher } \\
\text { success rates } \\
\text { (\% responders) } \\
\text { at } 12 \text { mo }\end{array}$ \\
\hline $\begin{array}{l}\text { Filardo et al (2010) } \\
\text { (Level III) }\end{array}$ & $\begin{array}{l}\text { Nonrandomized study, } \\
\text { PRP, } N=15 \text { vs. } \\
\text { physiotherapy } N=16 \\
\text { (matched for age, sex, } \\
\text { and sport level) } \\
\text { Chronicity }>3 \text { mo } \\
\text { and recalcitrant to } \\
\text { conservative and } \\
\text { surgical treatment } \\
\text { only in PRP the group }\end{array}$ & $\begin{array}{l}5 \text { mL L-PRP } \\
\text { Blood bank: (Plt: 6x; } \\
\text { WBC: ?) } \\
\text { Activated } \mathrm{Ca}^{2+} \mathrm{mEq} / \\
\text { dose }\end{array}$ & $\begin{array}{l}\text { Three blind injections/ } \\
\text { biweekly + physical } \\
\text { therapy } \\
\text { Comparator: physical } \\
\text { therapy/EQ-VAS, } \\
\text { Tegner score }\end{array}$ & $\begin{array}{l}6 \text { mo/No significant } \\
\text { improvement in PRP } \\
\text { group for EQ-VAS } \\
\text { and pain level. } \\
\text { Significant } \\
\text { improvement in PRP } \\
\text { group for Tegner score } \\
(+39 \text { vs. } 20 \%)\end{array}$ \\
\hline $\begin{array}{l}\text { Charousset et al }(2014)^{18} \\
\text { (Level IV) }\end{array}$ & $\begin{array}{l}\text { Case series, } N=28 \\
\text { athletes, } 17 \\
\text { professional, } 11 \\
\text { semiprofessional } \\
\text { PT refractory }\end{array}$ & $\begin{array}{l}6 \mathrm{~mL} \text { pure PRP } \\
(\mathrm{Plt}:>2 \mathrm{x})\end{array}$ & $\begin{array}{l}\text { Three US-guided } \\
\text { injections/VISA-P, VAS, } \\
\text { Lysholm }\end{array}$ & $\begin{array}{l}2 \text { year/21 athletes } \\
\text { returned to } \\
\text { presporting levels } \\
\text { at } 3 \text { mo } \\
57 \% \text { patients } \\
\text { recovered structural } \\
\text { integrity, } 7 \text { treatment } \\
\text { failures }\end{array}$ \\
\hline $\begin{array}{l}\text { Filardo et al (2013) } \\
\text { (Level IV) }\end{array}$ & $\begin{array}{l}\text { Case series, } N=43 \text {, } \\
\text { chronic }\end{array}$ & $\begin{array}{l}5 \text { mL L-PRP } \\
\text { Blood bank: (Plt: 6x; } \\
\text { WBC: ?) } \\
\text { Activated } \mathrm{Ca}^{2+} \mathrm{mEq} / \\
\text { dose }\end{array}$ & $\begin{array}{l}\text { Three US-guided } \\
\text { injections biweekly/ } \\
\text { VISA-P, Blazina, } \\
\text { EQ-VAS, Tegner, US }\end{array}$ & $\begin{array}{l}4 \text { y/VISA-P increased } \\
\text { over time, } 80 \% \text { were } \\
\text { satisfied and resume } \\
\text { previous sport } \\
\text { activities }\end{array}$ \\
\hline $\begin{array}{l}\text { van ArK et al }(2012)^{20} \\
(\text { Level IV) }\end{array}$ & $\begin{array}{l}\text { Case series, } N=5 \\
\text { patients, } 6 \text { tendons/ } \\
\text { athletes, symptoms } \\
\text { for over } 12 \text { mo } \\
\text { VISA-P }<80 \text {, US } \\
\text { hypoechogenicity, } \\
\text { recalcitrant to at least } \\
12 \text { wks eccentric } \\
\text { training }\end{array}$ & $\begin{array}{l}\text { 2-3 mL P-PRP } \\
\text { Plt: } 1.7 x \text { (ACP, Arthrex) }\end{array}$ & $\begin{array}{l}\text { Single US-guided } \\
\text { injection + physical } \\
\text { therapy } \\
\text { VISA-P, VAS during } \\
\text { daily activities, } \\
\text { functional test }\end{array}$ & $\begin{array}{l}6 \mathrm{mo} / 5 / 6 \text { tendons } \\
\text { showed an } \\
\text { improvement of at } \\
\text { least } 30 \text { points on the } \\
\text { VISA-P after } 6 \text { mo }\end{array}$ \\
\hline $\begin{array}{l}\text { Gosens et al }(2012)^{21} \\
(\text { Level IV) }\end{array}$ & $\begin{array}{l}\text { Case series } N=36, \\
\text { subgroups: refractory } \\
N=14 \text { vs. } \\
\text { nonrefractory } N=22 . \\
\text { Resistant to } \\
\text { conservative and } \\
\text { surgical treatment }\end{array}$ & $\begin{array}{l}3 \mathrm{~mL} \text { L-PRP (Plt: } 4-8 \mathrm{x} \\
\text { WBC: } 6 \mathrm{x} \text { ), buffered } \mathrm{pH} \text { : } \\
7.4+\text { bupivacaine/no } \\
\text { activation }\end{array}$ & $\begin{array}{l}\text { Single blind injection, } \\
\text { one skin portal, and } \\
\text { five penetrations of } \\
\text { the tendon } \\
\text { VISA-P, ADL, VAS }\end{array}$ & $\begin{array}{l}18 \text { mo/clinical } \\
\text { improvement in } \\
\text { refractory and } \\
\text { non-refractory } \\
\text { patients, better results } \\
\text { in the last group }\end{array}$ \\
\hline
\end{tabular}


Table 1 (Continued)

\begin{tabular}{|c|c|c|c|c|}
\hline \multicolumn{5}{|c|}{ Patellar tendon (conservative management) } \\
\hline $\begin{array}{l}\text { Study (year) } \\
\text { (Level of evidence) }\end{array}$ & $\begin{array}{l}\text { Study design, } N \\
\text { (patient population) }\end{array}$ & PRP (volume) & $\begin{array}{l}\text { Intervention/ } \\
\text { outcome } \\
\text { measurements }\end{array}$ & Follow-up/results \\
\hline & $\begin{array}{l}N=14, \text { resistant but } \\
\text { no injections, no } \\
\text { responders to } \\
\text { eccentric }\end{array}$ & & & \\
\hline $\begin{array}{l}\text { Kon et al }(2009)^{22} \\
(\text { Level IV) }\end{array}$ & $\begin{array}{l}\text { Case series } N=20 \\
\text { males } \\
\text { Refractory } \\
\text { tendinopathy }\end{array}$ & $\begin{array}{l}5 \mathrm{~mL} \text { L-PRP } \\
\text { Blood bank: (Plt: 6x; } \\
\text { WBC: ?) } \\
\text { Activated } \mathrm{Ca}^{2+} \mathrm{mEq} / \\
\text { dose }\end{array}$ & $\begin{array}{l}\text { L-PRP and } \\
\text { rehabilitation three } \\
\text { injections, } 2 \text { wk } \\
\text { interval between } \\
\text { injections/Tegner, } \\
\text { VAS, SF-36 }\end{array}$ & $\begin{array}{l}6 \text { mo/significant } \\
\text { improvement in all } \\
\text { scores after } 6 \text { mo. Six } \\
\text { men complete } \\
\text { recovery, eight men } \\
\text { marked improvement, } \\
\text { two men showed mild } \\
\text { improvement and four } \\
\text { men no improvement }\end{array}$ \\
\hline $\begin{array}{l}\text { Volpi et al }(2007)^{23} \\
\text { (Level IV) }\end{array}$ & $\begin{array}{l}\text { Case series } N=8 \\
\text { Young athletes, third } \\
\text { proximal recalcitrant } \\
\text { tendinopathy since at } \\
\text { least } 1 \mathrm{y}\end{array}$ & $\begin{array}{l}3 \mathrm{~mL} \text { L-PRP (Plt: } 4-8 \mathrm{x} \\
\text { WBC: } 6 \mathrm{x} \text { ) buffered } \mathrm{pH} \text { : } \\
\text { 7.4/no activation }\end{array}$ & $\begin{array}{l}\text { Single blind injection } \\
+ \text { rehabilitation/ } \\
\text { VISA-P, MRI }\end{array}$ & $\begin{array}{l}4 \text { mo/VISA } \\
\text { improvement (91\%)/ } \\
\text { reduction in } \\
\text { irregularity in } 80 \% \text { of } \\
\text { treated tendons (MRI, } \\
4 \text { mo) }\end{array}$ \\
\hline $\begin{array}{l}\text { Ferrero et al }(2012)^{24} \\
\left(\text { Level IV) }{ }^{\mathrm{a}}\right.\end{array}$ & $\begin{array}{l}\text { Case series } 28 \text { patellar } \\
\text { tendons in } 24 \text { patients } \\
\text { Competitive and } \\
\text { recreational athletes, } \\
\text { resistant to } \\
\text { conservative } \\
\text { treatments }\end{array}$ & $\begin{array}{l}\text { Blood bank: } 6 \mathrm{~mL} \text { L-PRP } \\
\text { Plt: } 5 x \text { WBC: } 6 x / \\
\text { thrombin activation }\end{array}$ & $\begin{array}{l}\text { US-guided two } \\
\text { injections and } \\
\text { scarifications } \\
\text { ( } 3 \text { wks interval)/ } \\
\text { VISA-P, US/6 mo }\end{array}$ & $\begin{array}{l}\text { VISA-P improvement } \\
\text { at } 6 \text { mo/reduction in } \\
\text { hypoechoic areas and } \\
\text { tendon thickness after } \\
6 \text { mo. Intratendinous } \\
\text { vascularity increased } \\
\text { at } 20 \mathrm{~d} \text { and } 6 \text { mo }\end{array}$ \\
\hline $\begin{array}{l}\text { Volpi et al }(2010)^{25} \\
\left(^{2} \text { Level IV) }\right.\end{array}$ & $\begin{array}{l}\text { Case series, patellar } \\
(N=13 \text { tendons), } \\
\text { nine athletes, other } \\
\text { recreational }\end{array}$ & $\begin{array}{l}3 \mathrm{~mL} \text { L-PRP (Plt: } 4-8 \mathrm{x} \\
\text { WBC: } 6 \mathrm{x} \text { ) buffered } \mathrm{pH} \text { : } \\
7.4 \text { no activation }\end{array}$ & $\begin{array}{l}\text { PRP and rehabilitation } \\
\text { Single US-guided } \\
\text { injection }\end{array}$ & $\begin{array}{l}\text { VISA-P, MRI//24 mo/ } \\
\text { Improvement in } \\
\text { VISA-P (+ } 37) \text { and } \\
\text { reductions in } \\
\text { abnormalities in } 80 \% \\
\text { of treated tendons } \\
\text { (MRI). The } \\
\text { improvement of } \\
\text { clinical symptoms is } \\
\text { maintained for at least } \\
2 \text { y following } \\
\text { treatment. } \\
\text { Improvement less } \\
\text { marked in Achilles }\end{array}$ \\
\hline
\end{tabular}

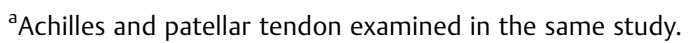

Abbreviations: ESWT, extracorporeal shock wave therapy; L-PRP, leukocyte-rich PRP; MRI, magnetic resonance imaging; Plt, platelets; PRP, platelet-rich plasma; PT, patellar tendon; RCT, randomized controlled trial; US, ultrasound; VISA-P, Victoria Institute of Sport Assessment-patellar; VAS, visual analog score; WBC, white blood cells; SF-12, health survey 12 questions; SF-36, health survey 36 questions.

score was significantly higher 4 years after the treatment and $80 \%$ of patients resumed their sporting activities thus were satisfied with the treatment. Results were worst in patients with bilateral PT, and in those with longer history of the pathology.

\section{Use of Platelet-Rich Plasma Fibrin to Regenerate Patellar Tendon Harvest Site}

PRP can enhance tissue regeneration in acute conditions as illustrated at the patellar tendon harvest site. The patellar tendon is often used for ACL reconstruction because of earlier bone to bone healing (-Table 2 ), mechanical qualities of the tissue, and ACL compatible size and shape. However, harvest site morbidity is reported in more than $40 \%$ of patients, including anterior knee pain, patellar stiffness, and loss of range of motion. ${ }^{26}$ Common sequelae are increased patellofemoral joint compression and late chondromalacia of the patella, and in some cases patellar fracture.

Three $\mathrm{RCT}^{27-29}$ have assessed the impact of filling the patellar harvest site with PRP Cervellini et $\mathrm{al}^{27}$ sutured PRP into the patellar harvest site in an RCT involving 40 patients, 20 per group. There were no differences in VAS scores at 
Table 2 Platelet-rich plasma treatment of patellar tendon harvest site

\begin{tabular}{|c|c|c|c|}
\hline $\begin{array}{l}\text { Study (year) } \\
\text { (Level of evidence) }\end{array}$ & $\begin{array}{l}\text { Number of } \\
\text { patients } \\
\text { PRP }\end{array}$ & $\begin{array}{l}\text { Outcome } \\
\text { assessments| } \\
\text { follow-up }\end{array}$ & Results \\
\hline $\begin{array}{l}\text { Cervellin et al }(2011)^{27} \\
\text { (Level I) }\end{array}$ & $\begin{array}{l}\text { RCT } N=40,20 \text { received PRP } \\
\text { PRP applied to patellar and } \\
\text { tendon bone plug } \\
\text { harvest site L-PRP } \\
\text { (GPS) } \mathrm{CaCl}_{2} \text { and } \\
\text { thrombin }\end{array}$ & VAS, VISA/12 mo & $\begin{array}{l}\text { VISA-P higher in PRP } \\
\text { group, no differences in } \\
\text { postoperative VAS } \\
>70 \% \text { of bone gap } \\
\text { filled: } 85 \% \text { in } P R P \text { vs. } \\
60 \% \text { controls } N / S\end{array}$ \\
\hline $\begin{array}{l}\text { de Almeida et al }(2012)^{28} \\
\text { (Level I) }\end{array}$ & $\begin{array}{l}\text { RCT } N=27, N=12 \text { receive PRP } \\
\text { Platelets } 7.65 x \text { leuko-depleted } \\
\text { clotted with autologous } \\
\text { thrombin prepared after } \\
\mathrm{CaCl}_{2} \text { addition to a } \\
\text { PRP aliquot }\end{array}$ & $\begin{array}{l}\text { MRI at } 6 \text { mo, isokinetic tests } \\
\text { VAS, functional } \\
\text { questionnaires, } \\
\text { Lysholm, IKDC, Kujala } \\
\text { and Tegner/6 mo }\end{array}$ & $\begin{array}{l}\text { Patellar tendon gap } \\
\text { significantly smaller in } \\
\text { PRP group. VAS lower in } \\
\text { PRP group. All groups } \\
\text { improved except for } \\
\text { Tegner. No differences } \\
\text { between groups. } \\
\text { No infections or } \\
\text { inflammatory } \\
\text { complications }\end{array}$ \\
\hline $\begin{array}{l}\text { Seijas et al }(2013)^{29} \\
(\text { Level I) }\end{array}$ & $\begin{array}{l}\text { RCT, PRP } N=23 \\
\text { control } N=20 \\
\text { Pure PRP, } 1-3 x \\
\mathrm{CaCl}_{2} \text { activated }\end{array}$ & $\begin{array}{l}\text { Maturity degree, vascularity } \\
\text { (Ohberg scale) Doppler } \\
\text { US-assessment/4, } 8,16,24 \text {, } \\
36,48 \text {, and } 96 \text { wks }\end{array}$ & $\begin{array}{l}\text { Differences in maturity } \\
\text { degree at } 16 \text { mo, } \\
\text { no differences at other } \\
\text { time-points. } \\
\text { No differences } \\
\text { in vascularity }\end{array}$ \\
\hline
\end{tabular}

Abbreviations: IKDC, International Knee Documentation Committee; L-PRP, leukocyte-rich PRP; MRI, magnetic resonance imaging; N/S, not significant; PRP, platelet-rich plasma; PT, patellar tendon; RCT, randomized controlled trial; US, ultrasound; VISA-P, Victoria Institute of Sport Assessment-patellar; VAS, visual analog score.

12 months, but the VISA-P score was higher in the PRP group. In another RCT, ${ }^{28} 12$ patients were treated with 20 to $40 \mathrm{~mL}$ of PRP, and compared with 12 patients in whom the donor harvest site was left untreated. At 6 months, the area of the patellar area treated with PRP was significantly smaller than the untreated area, as assessed by MRI. In addition, postoperative VAS scores were lower in the PRP group. A faster healing of the donor harvest site treated with PRP was also confirmed in another RCT performed by Seijas et al. ${ }^{29}$

\section{Use of Platelet-Rich Plasma in Medial Collateral Ligament Tears}

The MCL along with the anterior, posterior, and lateral cruciate ligaments are critical to maintain knee stability. Most often, MCL injuries occur as part of more complex knee injuries. At present, only a case report ${ }^{30}$ has been reported in an isolated Grade III MCL injury (Hughston classification). The athlete received three injections of L-PRP with 1-week interval and was followed-up for 16 months. The football player resumed sports activities at day 18 , and full competition at day 25 .

\section{Discussion}

The quality of the presently available evidence is insufficient to guide clinical decisions about PRP administration in PT because of the reduced number of controlled studies (three studies, of which two were RCTs). Despite that, the present published evidence mostly shows positive outcomes after
PRP management of PT. In case series, most patients treated with PRP with positive results were refractory to other conservative management. Implementation of PRP treatment seems reasonable before considering arthroscopic or surgical treatments. Of note, symptom exacerbation after PRP (or PRP + fat cells) treatment has been reported in three cases. ${ }^{31}$ Adverse reactions to PRP treatment can be very informative. Two of these patients had bilateral PT; one of them (a collegiate swimmer) received PRP mixed with abdominal fat in both knees while the second one (a professional volleyball player) received $3 \mathrm{~mL}$ of buffered L-PRP in each knee. The other patient (a high school basketball player) received two injections of pure PRP with 1-week interval.

The best PRP formulation and treatment regimen cannot be deduced from the present state of the art. ${ }^{32}$ In fact, the PRP formulation, the volume and number of injections, and whether injections are associated or not to tendon needling may influence outcomes. In PT, as in other tendinopathies, ${ }^{14}$ the most commonly used PRP formulation is L-PRP (seven vs. four studies). However, two of the three RCTs performed till date used two pure PRP injections, 1 or 2 weeks apart, with good results.

The optimal number of injections is controversial. More than one injection produces apparently more lasting results. ${ }^{19}$ This has sense from a biological perspective, since a single injection may be insufficient to induce sufficient cell migration, activation of local tendon fibroblasts, and enough synthesis of extracellular matrix proteins, to reverse cell apoptosis and the mucoid degeneration that has developed over months to years. Because the conditions of the host 
tissue may constrain the therapeutic response, it seems reasonable to speculate that the number and volume of injections should be tailored to each patient taking into account the severity of the injury, and the clinical response. Thus, appropriate treatment algorithms including demographic, clinical, and perhaps genetic polymorphisms data (associated to disease vulnerability) may help in identifying responders to PRP therapies.

Whether PRP is a palliative treatment or induces true regenerative changes in the tendon itself should be ascertained. Theoretically, if tendon regeneration is to be achieved through PRP injections, a long-lasting response is expected to accompany structural changes. Clinical and structural changes are not concomitant, but both long-lasting clinical effects and structural changes in the patella have been reported. In addition, the association of physical therapy to PRP injections may improve clinical and structural outcomes. $^{33,34}$

The phase of PT in which the patient should be treated with PRP is unclear. In fact, whether PRP is indicated for refractory tendinopathy or as a prior indication is arguable. Better results after a single L-PRP injection were found in nonrefractory patients, compared with recalcitrant patients in whom the condition was chronic. ${ }^{21}$ From these data, we may deduce that refractory patients need additional injections of PRP. Indeed, a 3-year follow-up case series study emphasizes the potential importance of a second PRP injection in painful tendon tears unresponsive to a single injection. $^{35}$

A recent cross-sectional retrospective survey gathered outcome data from different tendons treated with PRP. In this study involving a total of 180 patients, 106 patients were treated for PT and more than $80 \%$ of patients who received one or two injections and $76 \%$ of those who received three injections reported moderate-to-complete resolution of symptoms. ${ }^{36}$

In an acute injury context, in particular when grafting patellar tendon to reconstruct the ACL, the use of PRP fibrin to fill the hole left after graft harvest is clinically relevant. ${ }^{27-29}$ From a biological point of view, the PRP fibrin provides the necessary biological cues and structural support for cell activities (migration, proliferation, and extracellular matrix synthesis) and tissue regeneration. ${ }^{37}$ Preclinical research involving bilateral resection of the central half of patellar tendon $^{38}$ showed enhanced mechanical properties of the PRP treated site at 12 weeks.

The value of PRP injections for managing MCL injuries is under-researched. In fact, only one case report has been published. ${ }^{30}$ Preclinical studies, mainly performed in rabbits, showed enhanced healing of the MCL after pure PRP application. ${ }^{37-39}$ At 20 weeks, the ultimate failure load of the regenerated ligament was $78 \%$ of that in healthy controls. In accordance, when PRP was injected in the MCL of healthy rabbits new collagen deposition was found. ${ }^{40}$

PRP is a promising biological intervention applicable in the clinical setting. However, more research is needed to determine the optimal formulation, volume of PRP, number of injections and interval between injection and associated physical therapy. Given the heterogeneity of PRP protocols and the paucity of high quality data, the most effective approach to guide clinical decisions regarding PT cannot be deduced from present published studies. It is mandatory to generate high quality evidences before recommending this treatment to our patients. To further advance in the field, we have to conduct well-designed clinical studies assessing the potential therapeutic effect of PRP.

\section{References}

1 Zwerver J, Bredeweg SW, van den Akker-Scheek I. Prevalence of Jumper's knee among nonelite athletes from different sports: a cross-sectional survey. Am J Sports Med 2011;39(9):1984-1988

2 Lian OB, Engebretsen L, Bahr R. Prevalence of jumper's knee among elite athletes from different sports: a cross-sectional study. Am J Sports Med 2005;33(4):561-567

3 Panni AS, Cerciello S, Maffulli N, Di Cesare M, Servien E, Neyret P. Patellar shape can be a predisposing factor in patellar instability. Knee Surg Sports Traumatol Arthrosc 2011;19(4):663-670

4 van der Worp H, van Ark M, Zwerver J, van den Akker-Scheek I. Risk factors for patellar tendinopathy in basketball and volleyball players: a cross-sectional study. Scand J Med Sci Sports 2012; 22(6):783-790

5 Kettunen JA, Kvist M, Alanen E, Kujala UM. Long-term prognosis for jumper's knee in male athletes. A prospective follow-up study. Am J Sports Med 2002;30(5):689-692

6 Drumm O, Chan O, Malliaras P, Morrissey D, Maffulli N. Highvolume image-guided injection for recalcitrant medial collateral ligament injuries of the knee. Clin Radiol 2014;69(5):e211-e215

7 Crisp T, Khan F, Padhiar N, et al. High volume ultrasound guided injections at the interface between the patellar tendon and Hoffa's body are effective in chronic patellar tendinopathy: A pilot study. Disabil Rehabil 2008;30(20-22):1625-1634

8 Larsson ME, Käll I, Nilsson-Helander K. Treatment of patellar tendinopathy-a systematic review of randomized controlled trials. Knee Surg Sports Traumatol Arthrosc 2012;20(8):1632-1646

9 Maffulli N, Testa V, Capasso G, et al. Similar histopathological picture in males with Achilles and patellar tendinopathy. Med Sci Sports Exerc 2004;36(9):1470-1475

10 Bayer ML, Schjerling P, Herchenhan A, et al. Release of tensile strain on engineered human tendon tissue disturbs cell adhesions, changes matrix architecture, and induces an inflammatory phenotype. PLoS ONE 2014;9(1):e86078

11 Andia I, Sanchez M, Maffulli N. Tendon healing and platelet-rich plasma therapies. Expert Opin Biol Ther 2010;10(10):1415-1426

12 Magra M, Maffulli N. Molecular events in tendinopathy: a role for metalloproteases. Foot Ankle Clin 2005;10(2):267-277

13 Andia I, Maffulli N. Platelet-rich plasma for managing pain and inflammation in osteoarthritis. Nat Rev Rheumatol 2013;9(12): 721-730

14 Andia I, Maffulli N. Platelet-rich plasma for muscle injury and tendinopathy. Sports Med Arthrosc 2013;21(4):191-198

15 Dragoo JL, Wasterlain AS, Braun HJ, Nead KT. Platelet-rich plasma as a treatment for patellar tendinopathy: a double-blind, randomized controlled trial. Am J Sports Med 2014;42(3):610-618

16 Vetrano M, Castorina A, Vulpiani MC, Baldini R, Pavan A, Ferretti A. Platelet-rich plasma versus focused shock waves in the treatment of jumper's knee in athletes. Am J Sports Med 2013;41(4): 795-803

17 Filardo G, Kon E, Della Villa S, Vincentelli F, Fornasari PM, Marcacci $\mathrm{M}$. Use of platelet-rich plasma for the treatment of refractory jumper's knee. Int Orthop 2010;34(6):909-915

18 Charousset C, Zaoui A, Bellaiche L, Bouyer B. Are multiple plateletrich plasma injections useful for treatment of chronic patellar 
tendinopathy in athletes? a prospective study. Am J Sports Med 2014;42(4):906-911[Epub ahead of print]

19 Filardo G, Kon E, Di Matteo B, Pelotti P, Di Martino A, Marcacci M. Platelet-rich plasma for the treatment of patellar tendinopathy: clinical and imaging findings at medium-term follow-up. Int Orthop 2013;37(8):1583-1589

20 van Ark M, Zwerver J, van den Akker-Scheek I. Injection treatments for patellar tendinopathy. $\mathrm{Br} \mathrm{J}$ Sports Med 2011;45(13): 1068-1076

21 Gosens T, Den Oudsten BL, Fievez E, van 't Spijker P, Fievez A. Pain and activity levels before and after platelet-rich plasma injection treatment of patellar tendinopathy: a prospective cohort study and the influence of previous treatments. Int Orthop 2012;36(9): 1941-1946

22 Kon E, Filardo G, Delcogliano M, et al. Platelet-rich plasma: new clinical application: a pilot study for treatment of jumper's knee. Injury 2009;40(6):598-603

23 Volpi P, Marinoni L, Bait C, De Girolamo L, Schoenhuber H. Treatment of chronic patellar tendinosis with buffered platelet rich plasma: a preliminary study. Med Sport 2007;60(4):595-603

24 Ferrero G, Fabbro E, Orlandi D, et al. Ultrasound-guided injection of platelet-rich plasma in chronic Achilles and patellar tendinopathy. J Ultrasound 2012;15(4):260-266

25 Volpi P, Quaglia A, Schoenhuber H, et al. Growth factors in the management of sport-induced tendinopathies: results after 24 months from treatment. A pilot study. J Sports Med Phys Fitness 2010;50(4):494-500

26 Kartus J, Magnusson L, Stener S, Brandsson S, Eriksson BI, Karlsson J. Complications following arthroscopic anterior cruciate ligament reconstruction. A 2-5-year follow-up of 604 patients with special emphasis on anterior knee pain. Knee Surg Sports Traumatol Arthrosc 1999;7(1):2-8

27 Cervellin M, de Girolamo L, Bait C, Denti M, Volpi P. Autologous platelet-rich plasma gel to reduce donor-site morbidity after patellar tendon graft harvesting for anterior cruciate ligament reconstruction: a randomized, controlled clinical study. Knee Surg Sports Traumatol Arthrosc 2012;20(1):114-120

28 de Almeida AM, Demange MK, Sobrado MF, Rodrigues MB, Pedrinelli A, Hernandez AJ. Patellar tendon healing with platelet-rich plasma: a prospective randomized controlled trial. Am J Sports Med 2012;40(6):1282-1288

29 Seijas R, Rius M, Ares O, García-Balletbó M, Serra I, Cugat R. Healing of donor site in bone-tendon-bone ACL reconstruction accelerated with plasma rich in growth factors: a randomized clinical trial. Knee Surg Sports Traumatol Arthrosc 2013

30 Eirale C, Mauri E, Hamilton B. Use of platelet rich plasma in an isolated complete medial collateral ligament lesion in a professional football (soccer) player: a case report. Asian J Sports Med 2013;4(2):158-162

31 Bowman KF Jr, Muller B, Middleton K, Fink C, Harner CD, Fu FH. Progression of patellar tendinitis following treatment with platelet-rich plasma: case reports. Knee Surg Sports Traumatol Arthrosc 2013;21(9):2035-2039

32 Dohan Ehrenfest DM, Andia I, Zumstein MA, Pinto Zhang NR, Bielecki T. Classification of platelet concentrates (Platelet-Rich Plasma-PRP, Platelet-Rich Fibrin-PRF) for topical and infiltrative use in orthopedic and sports medicine: current consensus, clinical implications and perspectives. MLTJ 2014;4(1):3-9

33 Kaux J-F, Forthomme B, Namurois M-H, et al. Description of a standardized rehabilitation program based on sub-maximal eccentric following aplatelet-rich plasma infiltration for jumper's knee. MLTJ 2014;4(1):85-89

34 van Ark M, van den Akker-Scheek I, Meijer LT, Zwerver J. An exercise-based physical therapy program for patients with patellar tendinopathy after platelet-rich plasma injection. Phys Ther Sport 2013;14(2):124-130

35 Dallaudière $B$, Meyer $P$, Hummel V, et al. Efficacy of second intratendinous platelet-rich-plasma injection in case of incomplete response of the first injection: three-year follow up experience. Diagn Interv Imaging 2013;94(9):871-877

36 Mautner K, Colberg RE, Malanga G, et al. Outcomes after ultrasound-guided platelet-rich plasma injections for chronic tendinopathy: a multicenter, retrospective review. PM R 2013;5(3):169-175

37 Zhang J, Wang JHC. PRP treatment effects on degenerative tendinopathy: an in vitro model study. MLTJ 2014;4(1):10-17

38 Matsunaga D, Akizuki S, Takizawa T, Omae S, Kato H. Compact platelet-rich fibrin scaffold to improve healing of patellar tendon defects and for medial collateral ligament reconstruction. Knee 2013;20(6):545-550

39 Yoshioka T, Kanamori A, Washio T, et al. The effects of plasma rich in growth factors (PRGF-Endoret) on healing of medial collateral ligament of the knee. Knee Surg Sports Traumatol Arthrosc 2013; 21(8):1763-1769

40 Harris NL, Huffer WE, von Stade E, Larson AI, Phinney S, Purnell ML. The effect of platelet-rich plasma on normal soft tissues in the rabbit. J Bone Joint Surg Am 2012;94(9):786-793 